\title{
Achromobacter gen. nov. and Achromobacter xylosoxidans (ex Yabuuchi and Ohyama 1971) nom. rev.
}

\author{
EIKO YABUUCHI ${ }^{1}$ AND IKUYA YANO ${ }^{2}$ \\ Department of Microbiology, Kansai Medical University, Osaka 570, ' and Department of Bacteriology, \\ Niigata University Medical School, Niigata 951, ${ }^{2}$ Japan
}

\begin{abstract}
The names Achromobacter Bergey et al. 1923 and Achromobacter xylosoxidans Yabuuchi and Ohyama 1971 were not included on the Approved Lists of Bacterial Names. The name Achromobacter $x y$ losoxidans is here revived for the same organism to which the name was originally applied, and the new name Achromobacter is proposed for the genus in which this species is placed. $A$. xylosoxidans is the type species of Achromobacter, and ATCC 27061 is the type strain of $A$. xylosoxidans. The correct author citations for these names are Achromobacter Yabuuchi and Yano 1981 and A. xylosoxidans (ex Yabuuchi and Ohyama 1971) Yabuuchi and Yano 1981, or simply A. xylosoxidans Yabuuchi and Yano 1981.
\end{abstract}

The generic name Achromobacter Bergey et al., with the type species Achromobacter liquefaciens (Eisenberg) Bergey et al., was validly published and legitimate $(1,2)$. Achromobacter xylosoxidans was named by Yabuuchi and Ohyama (6) in accordance with the rules of the 1966 edition of the International Code of $\mathrm{No}$ menclature of Bacteria (3). Since this publication, many strains of $A$. xylosoxidans have been isolated and identified in clinical laboratories. This organism is an opportunistic pathogen of predisposed patients and is resistant to betalactam and aminoglycoside antimicrobial agents and to chlorhexidine disinfectants.

Because of the lack of an identifiable culture of $A$. liquefaciens, the generic name Achromobacter Bergey et al. was excluded from the Approved Lists of Bacterial Names (5). The name A. xylosoxidans was inadvertently omitted from the Approved Lists. In this paper we propose the name Achromobacter with a different type species, revive the name Achromobacter xylosoxidans, and thus give these names valid status according to the rules of the 1975 revision of the Bacteriological Code (4).

Achromobacter xylosoxidans (ex Yabuuchi and Ohyama 1971) nom. rev. (xylos ox'idans. M.L. xylos xylose; M.L.v. oxido make acid, oxidize; M.L. part.adj. xylosoxidans oxidizing $x y-$ lose).

Gram-negative, nonsporeforming, straight rods 0.8 to 1.2 by 2.5 to $3.0 \mu \mathrm{m}$, with rounded ends. Motile and peritrichous. The number of flagella is one to nine per cell. Strictly aerobic and nonfermentative. Definite acidity is produced promptly at the top of OF xylose medium without a paraffin seal. Oxidative acid produc- tion from glucose, galactose, mannose, and $\mathrm{D}$ arabinose is usually slow and weak. Indophenol oxidase and catalase positive; urease, gelatinase and deoxyribonuclease negative; 3 -ketolactose is

TABLE 1. Characters useful in the identification of A. xylosoxidans strains

\begin{tabular}{|c|c|c|c|}
\hline Character & Reaction & $\begin{array}{c}\% \text { Of } \\
\text { strains } \\
\text { positive }^{a}\end{array}$ & $\begin{array}{l}\text { Reac- } \\
\text { tion of } \\
\text { type } \\
\text { strain }\end{array}$ \\
\hline $\begin{array}{l}\text { Gram-negative, asporoge- } \\
\text { nous, straight rods }\end{array}$ & + & 100 & + \\
\hline Peritrichous cells & + & 98 & + \\
\hline Motility & + & 98 & + \\
\hline Indophenol oxidase & + & 100 & + \\
\hline $\begin{array}{l}\text { Open OF glucose me- } \\
\text { dium (acid) }\end{array}$ & $+b$ & $95(5)$ & $t^{b}$ \\
\hline $\begin{array}{l}\text { Sealed OF glucose me- } \\
\text { dium (growth) }\end{array}$ & - & 0 & - \\
\hline $\begin{array}{l}\text { OF maltose medium } \\
\text { (acid) }\end{array}$ & - & 0 & - \\
\hline OF xylose medium (acid) & + & 100 & + \\
\hline Citrate (Simmons) & + & 100 & + \\
\hline $\begin{array}{l}\text { Nitrate reduction to ni- } \\
\text { trite }\end{array}$ & + & 100 & + \\
\hline $\begin{array}{l}\text { Nitrite reduction to ni- } \\
\text { trogen gas }\end{array}$ & + or - & 64 & + \\
\hline $\begin{array}{l}\text { Urease and gelatinase } \\
\text { production }\end{array}$ & - & 0 & - \\
\hline $\begin{array}{l}\text { Hemolysis and discolora- } \\
\text { tion of rabbit blood }\end{array}$ & - & 0 & - \\
\hline $\begin{array}{l}\text { Lysine decarboxylase } \\
\text { (Carlquist ninhydrin) }\end{array}$ & - & 0 & - \\
\hline L-Arginine dihydrolase & - & 0 & - \\
\hline
\end{tabular}

${ }^{a}$ Based on a study of 55 strains. The values indicate the percentages of strains that were positive within 1 or 2 days. The value in parentheses indicates the percentage of strains positive after 3 or more days.

${ }^{b}$ Usually weaker than the acidity from xylose. 
TABLE 2. Fatty acid composition of extractable and bound lipids of five A. xylosoxidans strains

\begin{tabular}{|c|c|c|c|c|c|c|c|c|c|c|}
\hline \multirow{3}{*}{ Fatty acid ${ }^{a}$} & \multicolumn{10}{|c|}{ \% In A. xylosoxidans strains: ${ }^{b}$} \\
\hline & \multicolumn{2}{|c|}{ KM 543} & \multicolumn{2}{|c|}{ KM 954} & \multicolumn{2}{|c|}{ KM 955} & \multicolumn{2}{|c|}{ KM 1047} & \multicolumn{2}{|c|}{ KM 1051} \\
\hline & $\begin{array}{l}\text { Extract- } \\
\text { able }\end{array}$ & Bound & $\begin{array}{l}\text { Extract- } \\
\text { able }\end{array}$ & Bound & $\begin{array}{l}\text { Extract- } \\
\text { able }\end{array}$ & Bound & $\begin{array}{c}\text { Extract- } \\
\text { able }\end{array}$ & Bound & $\begin{array}{c}\text { Extract- } \\
\text { able }\end{array}$ & Bound \\
\hline $12: 0$ & $\mathrm{~T}$ & 1.0 & $\mathrm{~T}$ & $\mathbf{T}$ & $\mathbf{T}$ & 1.3 & $\mathbf{T}$ & 2.7 & $\mathbf{T}$ & 2.6 \\
\hline $14: 0$ & $\mathrm{~T}$ & 2.9 & $\mathrm{~T}$ & 1.9 & $\mathrm{~T}$ & 4.0 & 1.4 & 5.2 & $\mathrm{~T}$ & 3.5 \\
\hline $16: 0$ & 41.2 & 4.3 & 45.0 & 8.8 & 42.8 & 6.5 & 40.6 & 11.1 & 41.2 & 6.3 \\
\hline $16: 1$ & 35.9 & 1.6 & 7.5 & 1.0 & 11.9 & 1.0 & 21.7 & $\mathrm{~T}$ & 9.0 & $\mathrm{~T}$ \\
\hline $18: 0$ & 2.9 & 1.1 & 7.1 & 1.4 & 7.9 & 1.0 & 1.2 & $\mathrm{~T}$ & 5.1 & $\mathrm{~T}$ \\
\hline $18: 1$ & 6.6 & $\mathrm{~T}$ & 5.0 & 1.1 & 4.7 & $\mathrm{~T}$ & 8.1 & $\mathrm{~T}$ & 4.1 & $\mathrm{~T}$ \\
\hline $17 \mathrm{CPA}$ & 13.2 & $\mathrm{~T}$ & 35.0 & 2.5 & 31.7 & $\mathrm{~T}$ & 27.1 & 1.5 & 40.5 & 3.0 \\
\hline $19 \mathrm{CPA}$ & $\mathrm{T}$ & $\mathrm{T}$ & $\mathrm{T}$ & $\mathrm{T}$ & $\mathrm{T}$ & $\mathrm{T}$ & $\mathrm{T}$ & $\mathrm{T}$ & $\mathrm{T}$ & $\mathrm{T}$ \\
\hline $2 \mathrm{OH}-12: 0$ & $\mathrm{~T}$ & 33.6 & $\mathrm{~T}$ & 28.7 & $\mathrm{~T}$ & 25.6 & $\mathrm{~T}$ & 29.6 & $\mathrm{~T}$ & 31.3 \\
\hline $2 \mathrm{OH}-14: 0$ & $\mathrm{~T}$ & 22.4 & $\mathrm{~T}$ & 19.3 & $\mathrm{~T}$ & 21.2 & $\mathbf{T}$ & 16.6 & $\mathrm{~T}$ & 16.4 \\
\hline $3 \mathrm{OH}-14: 0$ & $\mathrm{~T}$ & 33.0 & $\mathrm{~T}$ & 34.5 & $\mathrm{~T}$ & 37.6 & $\mathrm{~T}$ & 31.1 & $\mathrm{~T}$ & 34.4 \\
\hline
\end{tabular}

a The number to the left of each colon refers to the number of carbon atoms, and the number to the right refers to the number of double bonds. CPA, Cyclopropane fatty acid.

${ }^{b}$ The values are percentages of total acids. T, Trace (less than 1\%); KM, Kansai Medical University.

not produced from lactose. The guanine-pluscytosine content of the deoxyribonucleic acid is in the range of 65 to $70 \mathrm{~mol} \%$. A detailed study and description of 75 phenotypic characters of 55 strains, the guanine-plus-cytosine contents of the deoxyribonucleic acids of 20 strains of this species, and a set of characters useful in the identification of $A$. xylosoxidans (Table 1) have been published previously (7). The major fatty acid components of cell-bound lipids are 2-hydroxydodecanoic acid (25.6 to 33.6\%), 2hydroxytetradecanoic acid (16.4 to $22.4 \%$ ), and 3-hydroxytetradecanoic acid ( 31.1 to $37.6 \%$ ) (Table 2). The respiratory quinone of $A$. xylosoxidans was reported to be ubiquinone $8(\mathrm{~K}$. Miyazaki, H. Kurose, Y. Fujimura, H. Kuraishi, M. Akagawa, and K. Yamasato, Abstr. Annu. Meet. Jpn. Soc. Ferment. Technol. 1980, p. 155).

A. xylosoxidans has been isolated from various kinds of pathological specimens, including blood, spinal fluid, pleural fluid, peritoneal fluid, pus, urine, stools, and swabs of eyes, ears, and pharynxes. Although its natural habitat is not known, this organism is frequently found in unsterilized "distilled" water and in chlorhexidine solutions in hospitals.

The type strain is ATCC 27061. The description of the type strain is identical to that of the species (Table 1).

Achromobacter gen. nov., not Achromobacter Bergey et al. 1923 (A chro mo bac'ter. Gr. adj. achromus colorless; M.L. noun bacter the masc. equivalent of the Gr. n. n. bactrum a rod or staff; M.L. masc. n. Achromobacter colorless rodlet).

Gram-negative, nonsporeforming straight rods which are motile and peritrichous. Strictly aerobic. Glucose and other pentoses and hexoses are oxidized to various degrees, but they are never fermented. Indophenol oxidase and catalase positive; 3-ketolactose is not produced from lactose. The respiratory quinone is ubiquinone 8. The guanine-plus-cytosine content of the deoxyribonucleic acid is in the range of 65 to 70 $\mathrm{mol} \%$.

A. xylosoxidans is the type species of the genus Achromobacter.

\section{REPRINT REQUESTS}

Address reprint requests to: Dr. Eiko Yabuuchi, Department of Microbiology, Kansai Medical University, Moriguchi, Osaka 570, Japan.

\section{LITERATURE CITED}

1. Bergey, D. H., F. C. Harrison, R. S. Breed, B. W. Hammer, and F. M. Huntton. 1923. Bergey's manual of determinative bacteriology, 1st ed. The Williams \& Wilkins Co., Baltimore.

2. Buchanan, R. E., J. G. Holt, and E. F. Lessel, Jr. (ed.) 1966. Index Bergeyana. The Williams \& Wilkins Co., Baltimore.

3. Editorial Board of the Judicial Commission. 1966. International code of nomenclature of bacteria. Int. J. Syst. Bacteriol. 16:459-490.

4. Lapage, S. P., P. H. A. Sneath, E. F. Lessel, V. B. D. Skerman, H. P. R. Seeliger, and W. A. Clark. (ed.). 1975. International code of nomenclature of bacteria. 1975 Revision. American Society for Microbiology, Washington D.C.

5. Skerman, V. B. D., V. McGowan, and P. H. A. Sneath (ed.). 1980. Approved lists of bacterial names. Int. J. Syst. Bacteriol. 30:225-420.

6. Yabuuchi, E., and A. Ohyama. 1971. Achromobacter xylosoxidans $\mathrm{n}$. sp. from human ear discharge. Jpn. J. Microbiol. 15:477-481.

7. Yabuuchi, E., I. Yano, S. Goto, E. Tanimura, T. Ito, and A. Ohyama. 1974. Description of Achromobacter xylosoxidans Yabuuchi and Ohyama 1971. Int. J. Syst. Bacteriol. 24:470-477. 